\title{
EDUCAÇÃO PÚBLICA, EDUCAÇÃO ALTERNATIVA, EDUCAÇÃO POPULAR E EDUCAÇÃO DO CAMPO: ALGUMAS LEMBRANÇAS E DIVAGAÇÕES
}

Carlos Rodrigues Brandẽo ${ }^{1}$

RESUMO: Este ensaio traz à luz o papel de Paulo Freire em diversos aspectos educacionais, mostrando o impacto do pensamento do educador, que se mostra atualizado até hoje.

Palavras-chave: Paulo Freire. Educação Pública. Educação Alternativa. Educação Popular. Educação no Campo.

\section{PUBLIC EDUCATION, ALTERNATIVE EDUCATION, POPULAR EDUCATION AND RURAL EDUCATION: SOME MEMORIES AND DIVAGATIONS}

\begin{abstract}
This essay brings to light the role of Paulo Freire in various educational aspects, showing the impact of the educator's thinking, which is still up to date.

Keywords: Paulo Freire. Public education. Alternative Education. Popular Education. Rural Education.

\section{EDUCACIÓN PÚBLICA, EDUCACIÓN ALTERNATIVA, EDUCACIÓN POPULAR Y EDUCACIÓN DE CAMPO: ALGUNOS RECUERDOS Y DIVAGACIONES}

RESUMEN: Este ensayo saca a la luz el papel de Paulo Freire en diversos aspectos educativos, mostrando el impacto del pensamiento del educador, que se actualiza hasta el día de hoy.

Palabras clave: Paulo Freire. Educación pública. Educación alternativa. Educación Popular. Educación en el campo.

1. Universidade Estadual de Campinas - Instituto de Filosofia e ciências Humanas - Departamento de Antropologia, Campinas (SP), Brasil E-mail: carlosdecaldas@gmail.com

Editora de Seção: Ivany Pino 


\section{Introdução}

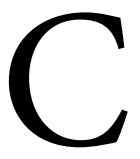

inquenta e quatro anos depois, o que há ainda para falar a respeito da educação popular? O que há para praticá-la? Quando? Junto a quem? Em nome de quem? Do quê? Como?

Um recente Fórum Internacional Paulo Freire reuniu em 2014 em Turim um número grande de pessoas para quem Paulo Freire e seu legado constituem, ainda, mais uma presença para pensar e agir hoje e agora do que uma mera memória que, de tempos em tempos, alguém relembra e festeja com pedagógica saudade.

Uma das experiências mais felizes que tenho vivido nos últimos "encontros "freireanos" (o próprio nome não é dos melhores) é a presença de jovens e adultos jovens mais numerosa do que a das "velhas testemunhas da História”, como eu mesmo. Entre alguns anos e outros, quando nos encontramos, nós, "os dos anos sessenta... quando tudo começou", lembramos os que partiram e recordamos os que já se sentem velhos e cansados o bastante para não se aventurarem mais a jornadas como a de Turim. Somos cada vez menos os que vivemos a ventura de partilhar com Paulo Freire não somente os seus escritos e suas ideias, mas um trecho de sua vida.

Nos anos que foram de 2011 a 2014 estivemos comemorando e recordando cinquentenários marcantes, sobretudo para os que viveram de forma direta ou indireta aquilo que juntos relembramos. Em 2011, festejamos os cinquenta anos da instauração da educação popular no Brasil e, depois, em toda a América Latina, a partir dos trabalhos da primeira equipe de Paulo Freire no Nordeste, a partir da criação de movimentos de cultura popular e de centros populares de cultura no Brasil. Em 2012, lembramos a realização no Recife do Primeiro Encontro Nacional de Movimentos de Cultura Popular. Pela primeira vez, nós nos reunimos para pensar juntos quem éramos e o que imaginávamos poder fazer. Por uma primeira vez e de uma forma tão afoitamente interativa, a educação abria-se à política, à pedagogia, à poesia, à ciência, ao teatro (lembrar o Teatro do Oprimido de Augusto Boal), à militância e à revolução.

Em 2013, vários de nós retornamos ao Nordeste para celebrar em Angicos, no Rio Grande do Norte, as primeiras experiências de alfabetização popular (e não apenas para o povo) com o novo Método Paulo Freire de Alfabetização. Mas em 2014 "desfestejamos" os cinquenta anos do golpe militar no Brasil. Poucos meses antes do golpe militar, Paulo Freire e a sua equipe haviam sido chamados a Brasília para impulsionarem uma ampla e radical campanha de alfabetização. Ela nunca foi sequer iniciada. Paulo Freire e tantos outros estiveram presos e foram exilados.

Quando nós, as pessoas que se reconhecem praticantes, militantes e participantes de algo que ao longo desses anos todos nos tem reunido ao redor da educação popular, colocamo-nos frente ao mundo em que praticamos essa modalidade humanista, crítica, criativa e transformadora da/através da educação, o que temos diante de nós é uma estranha e desafiadora realidade. Ela nos aparece como algo que, ao mesmo tempo em que dá continuidade aos trabalhos culturais-pedagógicos dos anos em que "tudo começou", hoje nos escancara uma face múltipla, ou mesmo faces plurais. Rostos e nomes de "educações" em boa parte diversas e, em alguns casos, quase divergentes daquilo que por muito tempo nos acostumamos a chamar de educação popular.

Não esqueçamos que nos "tempos originais", tanto para a cultura popular quanto para uma de suas vocações, realizada como uma ação social através da cultura - a educação popular -, o que nos movia eram palavras que continham ideias e acentuavam propostas regidas por participação, transformação, revolução. Transformação de estruturas da mente, da consciência, da cultura, da sociedade, do mundo. Transformações radicais (desde as raízes), estruturais (não de partes ou sistemas da sociedade, mas dela toda) e socialmente 
populares (centradas em lutas e políticas "de classe"). Ou seja, transformações de toda uma sociedade e não adaptações modernizadoras e ilusoriamente realizáveis de acordo com o estilo desenvolvimentista do sistema capitalista hegemônico.

Paulo Freire e outros muitos “educadores libertadores" - a expressão “educação popular” será tardia nos livros de Paulo - não foram exilados apenas porque pretendiam semear pelo País uma educação de cunho libertário e socialista - revolucionário, portanto. Foram presos e exilados por se voltarem contra uma educação do Estado colocada a serviço dos interesses hegemônicos da ordem do capital e, não raro, estreita e ardilosamente patriótica. ${ }^{1}$

Lembro que este escrito está dividido em tópicos que valem mais como crônicas críticas do passado e do presente do que como unidades orgânicas de um todo coerente, tal como se deveria esperar de um artigo sobre a educação. Quero acreditar que minhas palavras haverão de ser antecedidas e completadas por outras, de outros autores convidados a este colóquio-por-escrito. Pessoas que, desde anos mais próximos ao presente do que eu, saberão dar aos dilemas e caminhos de uma educação popular de hoje sentidos e rumos bastante mais convincentes e confiáveis do que eu.

\section{Educação Pública... Educação Popular?}

Fora locais e momentos de exceção - não raros efêmeros -, a educação pública surge na Europa em sua forma moderna junto com o nascimento dos estados-nação. Ela emerge e depressa se difunde em países submetidos a conflitos internos ou externos, em um tempo entre fins do século XVIII e início do século XIX, quando conflitos internos e guerras entre velhas e novas nações europeias eram mais a regra do que a exceção. Surgem, portanto, no interior e a serviço de sistemas políticos nacionais fortemente militarizados, entre os armamentos, os exércitos e a educação ofertada a crianças e a jovens. Um de seus locais de origem e acelerada expansão é a Prússia, o mais militar e belicoso dos países da Europa de seu tempo.

Seu modelo mais imediato é o exército e não a sociedade. Mais tarde e sob o impacto da Revolução Industrial, ela será a empresa e não a comunidade. Exceto breves momentos de exceção, à direita e à esquerda, uma educação pública de matriz europeia dirige-se através de suas escolas "abertas a todos" a instruir e formar crianças e jovens entregues à tutela de um poder de Estado empenhado em gerar cidadãos letrados, esclarecidos e disciplinados, ou seja, pessoas prontas a "viverem e morrerem pela Pátria”... ou pela empresa. Sabemos que o abecedário pedagógico de muitas de nossas escolas ainda começam com a letra "d", e da palavra "disciplina" derivam quase todas as outras. Uniformes, formaturas de estilo militar, cultos aos "símbolos da Pátria" são a sua rotina diária. Raros demais os currículos em que uma História da América justa e igualitária era ou segue sendo até hoje ensinada a crianças e a jovens. Um discreto acento humanista-iluminista apenas em parte escondia o teor uniformemente disciplinador da escola pública em suas origens. Entre outros estudiosos muito conhecidos é delas que fala Michel Foucault.

Em boa medida, essa é a primeira matriz de uma pedagogia normativa e oficial da escola pública dos séculos XVIII e XIX que as políticas públicas diferenciadamente importam para a América Latina.

A Inglaterra da Revolução Industrial trás para a educação pública sua outra face. Um país que desde cedo aprendeu a separar - ao estilo grego arcaico - a elite aristocrática e, depois, a burguesia florescente que deveria governar e administrar, da massa das "pessoas comuns" (professores incluídos) destinadas a obedecer e a trabalhar, reduziu no essencial o acento militarmente patriótico de suas escolas e incorporou a elas o que outros países da Europa tardaram a acrescentar às deles, e que depressa os Estados Unidos da América inovaram e tornaram o centro do espírito do ensino de suas escolas públicas: o foco sobre a formação 
de cidadãos competentes-competitivos direcionados à empresa e à indústria em tempos de paz, e às forças armadas em tempos de guerra. Algo cedo descoberto como outro "bom negócio". E essa tem sido, de forma acelerada nos últimos trinta anos, a outra face que também as nossas políticas públicas - com raras exceções em efêmeros momentos de outras políticas públicas - incorporam aos currículos de suas escolas.

À direita e à esquerda, entre as ideologias e os regimes políticos de vocação totalitária, praticamente todos os educadores, de Sócrates a Paulo Freire, foram colocados à margem. Foram por algum tempo tolerados e, depois, como os poetas, oficialmente proscritos ou "esquecidos". Em alguns contextos foram tidos como curiosos criadores de estranhas pedagogias e escolas "alternativas"; em outros, mais extremos, foram perseguidos, presos, exilados ou mortos. As ideias e as propostas pedagógicas cultural e/ou politicamente inovadoras, fora as raras exceções das diferentes escolas alternativas, de que as "antroposóficas" são talvez o mais conhecido e universalmente difundido exemplo, são aceitas como experiências singulares, quase sempre dirigidas "aos que podem pagar". E quando, em outra direção, são criadas pelo operariado e diretamente dirigidas ao povo, desde o século XIX às ditaduras latino-americanas do século passado, elas passam a ser severamente perseguidas e, aqui e ali, fechadas, não raro entre tiros e prisões. Foi isso o que ocorreu com as "escolas anarquistas" de vocação libertária durante algum tempo implantadas no Brasil por operários emigrantes europeus e dirigidas a filhos de trabalhadores. ${ }^{2}$

Uma "educação pública popular" é quase sempre efêmera, ou deprava-se como uma educação pública submetida a um poder de Estado através da subserviência do povo ou, principalmente, quando se anuncia como uma educação a "serviço da sociedade civil". No Brasil, durante a vigência do Partido dos Trabalhadores no governo da Federação, no de alguns estados e nos inúmeros municípios, a "educação popular" foi decretada oficialmente como a própria "política da escola pública". Foi então o breve e fecundo tempo da criação de "escolas cidadãs", de "escolas candangas", de outras "escolas populares" com outros nomes e de uma declarada vocação comunitária e participativa. Foi o tempo das assembleias populares sobre a educação, dos coletivos pedagógicos, das gestões partilhadas, dos orçamentos participativos, das pesquisas prévias junto às comunidades de acolhida das escolas para a elaboração de propostas curriculares questionadoras. Hoje, fora alguns contextos muito raros, de tudo o que se fez, resta a memória saudosa de algumas professoras e algumas dissertações e teses de pós-graduação.

Em anos não tão distantes Paulo Freire foi oficialmente decretado Patrono da Educação Brasileira, e o Ministério da Educação elaborou um documento que funda na educação popular a política pública de educação no País. Nada há no horizonte que torne uma confiável prática esta vaga proposta. Ao contrário, pessoas que militam no Conselho Nacional de Educação resistem como podem a um avanço evidente e crescente do ideário neoliberal, defensor da "escola para a empresa" e da "educação como negócio".

A citação abaixo poderia ser tomada como o "mote" de apenas uma face das críticas que educadores contrários a esse horizonte pedagógico oficial no Brasil fazem à escola pública:

Numa breve perspectiva histórica, na América Latina, especialmente no Brasil, a escola pública não tem sido uma instituição pensada para o acolhimento das classes populares. ... $\mathrm{Na}$ América Latina, nos países cujos modelos políticos e econômicos se pautam pela ideologia desenvolvimentista, a escola, especialmente a escola pública, teve como um de seus principais objetivos, junto às classes populares, prepará-las para o mundo do trabalho, garantindo uma força de trabalho minimamente educada, além de inculcar e difundir a ideologia liberal de aceso e democratização do conhecimento socialmente produzido para todos. (ESTEBAN; TAVARES, 2013, p. 293) 
Conhecemos de sobra algumas razões visíveis a respeito da distância, ou mesmo de uma dissonância entre a educação pública estatal e a educação popular. Uma delas é difundida o bastante para não ser mais do que apenas sumariamente relembrada aqui. A educação popular não se apresenta como um serviço cultural através da educação estendida ao povo, mas como uma ação pedagógica colocada a serviço do povo. Colocada, na contramão, a serviço direto de sua formação e de seu crescente e irreversível empoderamento como um agente ativo de transformações sociais quase sempre hostil a poderes de Estado liberais, neoliberais ou liberalmente populistas. Hostil a tais políticas e, mais ainda, aos interesses dos polos político-econômicos os quais servem a um poder público colonizado.

Mas há também um outro um motivo do descolamento entre a educação popular e as nossas políticas governamentais de educação. E ele tem sido sutilmente o mais esquecido. Ao deslocar de um poderde-estado para instituições e frentes de lutas populares o seu lugar de inserção, a educação popular desqualifica a essência de um teor nacionalista-patriótico de qualquer educação pública. Veremos mais adiante como a educação popular, a partir de Paulo Freire, em muito breve tempo passa de "nordestina" a "brasileira", de "brasileira" a "latino-americana" e de "latino-americana" a "altermundista". Altermundista aqui num duplo sentido da palavra: primeiro, universalista a partir das classes e dos movimentos populares - de que hoje em dia a Via Campesina é um exemplo eloquente -; segundo, integrada ao princípio de que cabe ao povo — nós incluídos, segundo a minha visão - a criação de "um outro mundo possível".

Assim, como um educador popular, diante do enfrentamento entre movimentos camponeses paraguaios e a política expansionista de meu País, o Brasil, eu me coloco ao lado dos camponeses paraguaios e contra a política agrária de meu País. E com eles aproveito para aprender a reler uma outra versão da Guerra da Tríplice Aliança. Um conflito até hoje ensinado em nossas escolas como uma triunfante "Guerra do Paraguai".

Uma primeira lição difícil de ser aprendida entre nós é a de que a partir do momento em que, "para além do nacional", você se coloca "ao lado do povo", toda essa criação das elites governantes chamada: "nacionalismo", torna-se algo a superar em nome de um pan-universalismo popular, popular e desfronteiradamente fraterno.

\section{Educação Popular e o Desafio do Diálogo}

Há pelo menos duas variantes na compreensão do que seja a educação popular: a primeira é uma modalidade de pensamento, de prática pedagógica e de ação política dela derivada, dirigida às/pelas classes populares e devotada a participar de processos em que elas se tornam protagonistas de transformações sociais. Ela surge por volta dos anos 1960 na América Latina e radicaliza teórica, pedagógica e politicamente o que também na Europa foi em alguns momentos e lugares chamado de educação popular. Isso porque ela não se dirige como um serviço suplementar de educação às camadas populares, mas porque ela pretende se colocar pedagogicamente a serviço das classes populares para que elas próprias estabeleçam o seu destino como classe e o teor de suas ações políticas transformadoras; a segunda, aquilo a que damos agora o nome de educação popular, é algo que ao longo da trajetória humana aconteceu e segue acontecendo em diferentes momentos e em diversos lugares sociais. Com diversas assinaturas e ideologias políticas e propostas pedagógicas de sua realização, emerge o acontecer de uma educação popular sempre que uma crítica radical a um poder político, a uma hegemonia econômica, a uma colonização cultural através inclusive de uma educação se associa a um projeto originado das classes populares ou assumido por elas como seu. Um projeto que justamente repensa a educação como cultura, a cultura como política e a política como transformação social de vocação popular. 
No caso brasileiro e para ficarmos aqui na escolha da primeira alternativa, lembremos que, embora os movimentos de cultura popular da aurora dos anos 1960 surjam tanto "no campo" quando "na cidade", em sua vocação freireana e mais difundida, uma educação popular é dirigida diretamente ao campesinato situado nas regiões mais pobres e menos desenvolvidas do Brasil: o Nordeste, o Centro-Oeste e a Amazônia. As primeiras experiências nordestinas de fato marcantes são rurais, a começar por As Quarenta Horas de Angicos. E o Movimento de Educação de Base, a mais expandida e expressiva instituição derivada dos movimentos de cultura popular (MCPs), é absolutamente rural. Entre a educação popular dos anos 1960 apenas tardiamente assumida com o nome "educação popular" - e a educação do campo, que trago a este artigo, há um intervalo de mais de cinquenta anos.

Ora, uma peculiaridade nuclear da educação popular desde suas origens remotas até os dias de hoje a separa ideológica, política e pedagogicamente de outras vertentes de educações de vocação classista, transformadora e revolucionária. No imaginário da educação popular não deve existir um polo central, uma agremiação de teoria-e-prática, um partido ou o que seja com poderes de gestão e direção dos processos de saber-fazer, no encontro entre um "nós" educadores populares não "do-povo", e “eles", educadores populares no duplo sentido da palavra "popular".

A educação popular consagra no diálogo não apenas uma metodologia de valor e de atuação pedagógica, de que o "círculo de cultura" seria a mais conhecida imagem. O diálogo é, nela, o começo e o final de todo o acontecer do ensinar-a-aprender. Em suas formas mais radicais - aquela que eu pessoalmente assumo - , a sua "palavra de ordem" é uma assumida e inicial "desordem pedagógica". É a ideia de que, com um mínimo de propostas de base, tudo o que se realiza como e através da educação popular parte de um encontro tão igualitário quanto possível e imaginado de saberes e significados. De uma "turma de alfabetizandos" a uma instituição ampla de criação de uma "proposta de educação popular", são coletivos tão igualados e igualitários de poder de pensar, dizer e decidir aqueles que geram e gerenciam um trabalho de educação popular.

A simples leitura da "bibliografia" ao final de uma "linha do tempo" que vai dos primeiros livros e artigos de educação popular até os mais atuais deixará claro que mesmo quando uma crítica da sociedade possui em autores como Marx e Gramsci os seus fundamentos, a partir do próprio Paulo Freire, uma vocação dialogicamente humanista - entre as infinitas variações desta ampla e, não raro, vaga palavra — será sempre o seu horizonte. E isso nos acompanha até hoje se quisermos ser francos e transparentes. Desde o começo dos anos 1960, Cuba nos foi um horizonte - inclusive para militantes cristãos - e a educação cubana nos era um modelo escolar. Mas pensadores e educadores cubanos foram e seguem sendo entre nós educadores populares latino-americanos, absolutamente raros. Até onde posso me lembrar, eles não comparecem nos livros de coletâneas de textos mais recentes. Deixo em aberto essa intrigante questão.

Em um livro a meu ver absolutamente atual, Alfonso Torres Carrilo acentua esse suposto, com o justificável equívoco de reconhecer em Paulo um cristão, o que de fato ele nunca assumiu ser, embora boa parte de sua obra tenha sido publicada por instituições cristãs e, durante o exílio na Europa, ele tenha respondido pelo Setor de Educação do Conselho Mundial das Igrejas (o Vaticano das confissões protestantes).

A militância cristã de Freire e o carácter humanista de sua proposta fez com que sua proposta tivesse acolhida dentro da Igreja; primeiro o MEB do Brasil (o Movimento de Educação de Base, ao qual pertenci - CRB) assume a sua metodologia e posteriormente a Conferência Episcopal de Medellín (1968); deste modo os fundamentos e a metodologia de Freire influem naquilo que posteriormente seria a Teologia da Libertação. Muitos religiosos e cristãos comprometidos com os pobres veriam na Educação Conscientizadora a metodologia mais coerente com as ações pastorais e educativas. (TORRES CARRILLO, 2012, p. 28$)^{3}$ 
Ainda que as palavras acima possam ser relativizadas, sobretudo quando estendidas ao contexto de toda a América Latina, não deve haver quem duvide de que esse foi sempre um dos pontos mais polêmicos e críticos nos diálogos entre militantes de uma educação popular de vocação freireana e outros que, em nome de uma ação política mais diretamente classista, defendem que as propostas de transformações da sociedade e de uma formação política das classes populares devem ser mais diretivamente centrada em polos partidários, ou não.

A radicalidade de uma pedagogia centrada num diálogo entre pessoas, culturas e classes sociais na construção de cada momento, e do todo do acontecer da educação, foi e segue sendo desde os anos pioneiros até o momento presente, ao mesmo tempo a força humanamente pedagógica e a debilidade política da educação popular. Não apenas as ideias, mas as experiências pessoais de Paulo Freire e de incontáveis seguidores seus ao longo do tempo são a própria evidência de uma coisa e da outra. Ele foi ao longo de toda a sua vida um defensor radical da dialogicidade na/da educação. Sou testemunha ocular da maneira como Paulo Freire não aceitava, sob pretexto algum, a imposição não apenas de ideias — inclusive as suas - mas também de propostas e projetos pré-construídos por unidades de educadores e, depois, "levadas prontas" ao povo. Um dos entraves de sua atuação como educador junto ao Partido dos Trabalhadores esteve sempre em sua não aceitação de que em programas de educação um partido qualquer pudesse "levar pronta" uma proposta, mesmo quando saída de debates entre os seus dirigentes ou militantes mais diretamente ligados à educação.

\section{Educação Pública, Educação Alternativa, Educação Popular e Educação do Campo}

Um dos mais estranhos costumes de antropólogos é o deixar de procurar compreender “o que está acontecendo" com o olhar dirigido a macrodimensões da política, da economia e de outros amplos campos da sociedade, como o das "políticas públicas de educação", e simplesmente procurar "olhar ao redor". É o que farei desarmadamente aqui.

Quando percebo como procedem as "pessoas comuns" (eu incluso) ao meu redor; quando procuro compreender o que pensam, em que fundamentos se baseiam e como agem e em nome do quê; quando leio o que leio - e não apenas nos "livros e artigos de ponta", mas também nas inúmeras revistas sobre a educação editadas por instituições da sociedade civil, por secretarias municipais de educação (prática muito comum no Brasil) ou mesmo compradas em bancas de jornaleiros -; quando acompanho não tanto os "grandes debates sobre a educação no Brasil e no mundo", mas as conversas de corredores de escolas, ou mesmo de mesas de bar (sempre caras a Paulo Freire), constato que as pessoas com quem convivo, as que leio e me são próximas, as que estudo a fundo e de quem sigo aprendendo, eu as encontro repartidas, no que toca a educação, segundo uma distribuição que sumariamente poderia ser desenhada assim:

1. Algumas pessoas estão empenhadas em trabalhar intensamente em favor da educação e da escola pública, seja porque são educadores e/ou gestores da educação, vinculados a alguma instituição oficial do poder público federal, estadual ou municipal, seja porque são educadores e docentes de universidades públicas. Nestes casos, elas defendem a primazia de uma "educação pública, democrática, cidadã, de qualidade e ofertada a todas e todos". De igual maneira, procedem aqueles que agem como militantes de sindicatos ou de outras instituições classistas-docentes, como algum ramo da Central Única dos Trabalhadores (CUT). Vários dos mais conhecidos e consequentes educadores e pensadoras da educação no Brasil se situam nesta opção. 
2. Algumas pessoas se identificam publicamente como educadores populares; reconhecem-se como seguidoras das ideias originárias de Paulo Freire e de outros pioneiros da educação popular no Brasil e na América Latina; e, ao lado de uma afiliação ao ideário de defesa da escola pública, agregam a isso uma militância direta junto a agremiações e movimentos populares. Existem várias agremiações da sociedade civil, como o Instituto Paulo Freire, especificamente dedicadas a estudos, pesquisas, propostas e práticas de uma "educação popular”. De igual maneira, movimentos sociais populares com frequência se afirmam como afiliados à educação popular. Em termos de América Latina, o Conselho Latino-Americano de Educação de Adultos é, desde há vários anos, o mais reconhecido porta-voz de uma educação popular freireana. ${ }^{4}$

3. Algumas pessoas - cujo número tem crescido nos últimos anos - lançam-se em projetos e ações de criação de "escolas alternativas" em busca de "uma outra educação". Sob esse nome estou alocando aqui desde experiências vindas da Europa ou dos EUA, de que a Escola Antroposófica e sua Pedagogia Walldorf constituem a experiência mais conhecida e difundida no Brasil, até recentes iniciativas de criação de cooperativas de educação, de escolas comunitárias, ou de escolas criadas em nome de uma moderada ou mesmo radical transferência do foco da educação do "ensino de quem educa" para a "aprendizagem de quem se educa". ${ }^{5}$

Dentre as pessoas que se afiliam a um difuso e não institucionalizado "movimento de educação alternativa”, entrevejo duas vocações polares. Uma é a das pessoas preocupadas com “a formação de meus filhos" e adeptas de uma educação especial altamente qualificada e de ampla liberdade de ação e pensamento, em geral afiliadas a escolas alternativas pagas e caras. Outra é a vertente das pessoas que se lançam em busca de uma "alternativa de educação" que possa ser ampliada e democraticamente difundida a partir de experiências pioneiras, se possível invadindo o próprio território da educação pública. Pensadores que vão de Tolstoi, O’Neill, Rousseau, Claparede, Freinet, Montessori a outros educadores mais recentes e ainda vivos são suas fontes de origem.

4. Finalmente, há pessoas que em linha direta e desde o começo dos anos 1960 até hoje identificam-se também como educadores populares, e acreditam-se envolvidos com teorias, propostas e práticas da educação popular. Mas será entre elas que uma diferenciação tenderá a se estabelecer e ampliar, sobretudo nos últimos trinta anos.

É importante levar em conta que, mesmo tendo ainda "nas ideias de Freire" o seu fundamento, algumas pessoas e agremiações praticantes de alguma modalidade de educação popular reconhecem que "os tempos são outros", cinquenta e alguns anos após a publicação dos primeiros escritos da "equipe pioneira". Assim sendo, e que face a acontecimentos bastante conhecidos, entre dimensões internacionais, latinoamericanas e nacionais (sobretudo entre os países que atravessaram tempos de governos militares) não apenas conjunturas de ação, mas até mesmo fundamentos e horizontes da educação popular foram e seguem sendo reconceitualizados. Na verdade, a expressão utilizada por alguns educadores populares da atualidade é refundamentação da educação popular. Que uma vez mais nos fale Alfonso Torres Carrillo. Referindo-se em 2007 a um livro seu de 2000, ele afirma isto:

Para Alfonso Torres (2000:21) a refundamentação está associada a múltiplos fatores como o esgotamento dos referentes discursivos a respeito da pluralização de práticas e atores da EP, a crise do socialismo histórico e a atração exercida por novas colocações teóricas provenientes das ciências sociais; "desde mediados dos oitenta começamos a sentir uma certa insatisfação 
a respeito dos discursos que orientavam as nossas experiências, eles nos pareciam limitados para dar conta do que estávamos fazendo; os referentes teóricos com que interpretávamos a realidade, orientávamos os projetos e compreendíamos os sujeitos que os protagonizavam não expressavam tudo o que queríamos dizer ou não correspondia à realidade sobre a qual estávamos atuando. (TORRES CARRILLO, 2012, pp. 77-78) ${ }^{6}$

Acredito que os termos e os rumos da refundamentação da educação popular a partir dos anos 1980 sejam bastante conhecidos. No entanto é ainda em diálogo com Alfonso Torres Carrilo que eu pretendo sintetizar alguns deles.

A partir do próprio Paulo Freire em seus últimos escritos, a educação popular abre-se a um diálogo com outras modalidades de ação social - no que recupera em boa medida a tradição original vinda da cultura popular dos anos 1960 no Brasil — com a contribuição de outras e pluridiversas teorias e propostas vindas das ciências sociais e de ramas humanistas da filosofia, com diversas vocações outras da própria educação, inexistentes ou incipientes nas duas décadas antecedentes, como a educação dos (e não apenas "para os") movimentos sociais, a educação ambiental, a educação para a paz, a educação e direitos humanos, e outras mais. Na verdade, é preciso lembrar que a redemocratização relativa de países da América Latina e o empoderamento de alguns movimentos populares forçaram a própria educação popular, pelo menos em algumas de suas vertentes mais próximas a tais movimentos e frentes de luta, a se colocarem como instâncias de apoio político-pedagógico a ações educativas presentes e ativas nos/dos próprios movimentos populares. Mais adiante nos encontraremos com a educação do campo como uma de suas modalidades.

De outra parte, algumas vocações mais recentes e unidirecionadas de educações posteriores não raro se aproximavam da educação popular e identificavam suas práticas setoriais como também "populares". Esse é o sentido em que aqui e ali se fala em educação ambiental popular.

Essa abertura inevitável em múltiplas direções e em diálogo com diversos atores sociais levou a educação popular em boa medida a migrar de uma exclusiva ou prioritária "leitura classista ortodoxa da sociedade à incorporação de outras perspectivas e categorias analíticas como hegemonia, movimentos sociais, sociedade civil e sujeitos sociais" (TORRES CARRILLO, 2012, p. 78). A própria categoria "povo" passou a receber diversos e, não raro, divergentes sentidos entre educadores populares. Esse é também o tempo histórico em que, sobretudo em países pluriétnicos e culturais, como o Brasil, outros atores étnicos, culturais e sociais se fazem presentes e obrigam a própria educação (inclusive as das políticas públicas) tanto a uma completa revisão de seus conteúdos pedagógicos, quanto à incorporação de novas escolas e educações. São exemplos no Brasil a educação indígena e a educação em comunidades quilombolas.

Também serão os educadores populares desses países os mais sensíveis a incorporar ao círculo dos saberes, sentidos, significados, sensibilidades e sociabilidades de "outros povos e de outras culturas", o núcleo não apenas do campo teórico-ideológico dos saberes, mas também ao de suas outras éticas, estéticas, eróticas e políticas.

Uma pedagogia "conscientizadora e politizadora", destinada em seu horizonte a transformações radicais da sociedade através de uma conquista popular do poder, tende a ser relativizada e repensada no campo das diferenças entre os diversos contextos sociais. Ainda que para a maior parte dos educadores populares o povo - no sentido original de classe-para-si - seja o ou um sujeito protagônico dos processos de luta e mudança social, há um alargamento do sentido político das próprias transformações a serem processadas e seus horizontes.

A persistente crise da busca de um modelo histórico de sociedade para além da capitalista parece estar exercendo junto a muitos pensadores do presente e do futuro próximo uma descrença não apenas 
na viabilidade de uma transformação social em direção a um outro modelo, como também até mesmo o horizonte da possibilidade de um projeto de futuro em nome de um mundo que desloque do mercado e do capital para o ser humano e o mundo da vida social, o eixo de poder de transformação do presente e de gestação e gestão de um "outro futuro".

Sensível a um diálogo com vertentes de pensamento teórico, de construção do conhecimento e de suas derivações para a educação fundadas em autores que não raro provêm mais da física quântica e da biologia do que da economia e da política, desde alternativas bastante diferenciadas, educadores populares acolhem novas compreensões de fundo "holístico", "multicultural", "integrativo-interativo" e dialogicamente “transdisciplinar". Essa derivação inevitável, ao ver de alguns, desloca uma primazia da questão social de um plano socioeconômico em direção a compreensões mais totalizadoras tanto do acontecer humano quanto da complexidade da sociedade.

Tal como ocorre no interior e em áreas de fronteira das próprias vertentes marxistas da educação, entre educadores populares de agora, questões relacionadas à individualidade, à identidade, à afetividade e à conectividade centrada em dimensões que chegam a submeter a racionalidade à afetividade, tendem a constituir cada vez mais o próprio centro das reflexões teóricas sobre conhecimento-consciência e, por consequência, as linhas de direção de uma educação que somente pode ser "popular" se for popularmente sensível e totalizantemente humanizadora.

Enfim, mesmo entre os herdeiros mais fiéis das tradições originais freireanas, na trilha dos próprios últimos escritos de Paulo Freire, educadores populares latino-americanos migram da unicidade de metodologias de pedagogia e pesquisa, centradas de forma direta ou indireta em abordagens dialéticas, em direção ao diálogo com outras correntes de pensamento e ação. Nesse sentido e apenas como um exemplo entre outros, creio ser oportuno chamar a atenção para um deslocamento recente e essencial, pelo menos no caso brasileiro. Após muitos anos de absoluto distanciamento de pensadores e educadores portugueses, hoje em dia o Brasil se abre a um diálogo expressivamente crescente com pedagogos de universidades de Portugal. E um fecundo e pluridirigido diálogo com pessoas como Antônio Nóvoa e Boaventura de Souza Santos é bem a mostra dessa fecunda e tardia evidência. Lembro também apenas de passagem que Paulo Freire foi e se reconhecia publicamente como um educador fortemente influenciado por Franz Fanon. Em mais de uma ocasião ele nos confidenciou que não raro aprendia mais com os seus "mestres africanos", como Samora Machel e Amilcar Cabral, do que com reconhecidos pensadores da Europa.

Creio que, entre teóricos essenciais da educação brasileira, talvez o momento da "refundamentação da educação popular" apenas tenha retomado uma clivagem entre compreensões "dialógicas" e "dialéticas" que, na verdade, já estavam criticamente presentes na complexa polêmica sobre o sentido de "cultura popular" dos primórdios dos anos 1960. Momentos essenciais dessa polêmica estão em alguns artigos reunidos por Osmar Fávero em Cultura Popular e Educação Popular - memória dos anos sessenta, já citado aqui. Essa é uma clivagem que acompanhará a trajetória da educação popular e de outras pedagogias de vocação emancipatória durante as suas trajetórias e até o momento presente, e mais à frente veremos um sinal de sua atualidade no Brasil de agora.

Demerval Saviani e outros intelectuais de reconhecida importância irão se afastar de uma definida vertente freireana da educação popular. Saviani irá elaborar a teoria de uma pedagogia histórico-crítica. ${ }^{7}$ Sua proposta pedagógica esteve restrita ao âmbito estritamente acadêmico durante vários anos, ao contrário do que ocorreu desde as suas origens com a educação popular, que ingressou inicialmente na universidade pela porta dos fundos e até hoje em algumas delas dificilmente consegue chegar até a sala de visitas.

Acredito que uma definida vertente dialética esteve sempre presente no ideário e nas propostas de uma pedagogia militante em diferentes movimentos populares na América Latina. Penso que, no Brasil, ela é 
a (ou uma das) principal fonte de ideias, propostas pedagógicas e projetos concretos de educação e escola de movimentos populares hoje envolvidos em frentes de luta pela conquista de diversos territórios: de territórios da terra onde se planta a territórios do saber que se semeia.

\section{O Surgimento da Educação do Campo}

A recente educação do campo talvez seja a sua melhor evidência. E não ao acaso Demerval Saviani é um dos autores mais lembrados entre os verbetes do Dicionário da Educação do Campo, cuja primeira edição é, relembro, já do século XXI, assim como os documentos que estabelecem a sua proposta. ${ }^{8}$ De igual maneira, nesse dicionário Paulo Freire é lembrado de passagem, quando não omitido, e quase sempre apenas através do Pedagogia do Oprimido. O mesmo acontece com outros educadores populares da vertente freireano-dialógica, à exceção justamente do verbete: educação popular.

O Dicionário da Educação do Campo trás os seguintes longos verbetes relacionados à educação: educação básica do campo, educação corporativa, educação de jovens e adultos, educação do campo, educação ominilateral, educação politécnica, educação popular, educação profissional, educação rural. Entre todos os verbetes, escritos por educadores de linha dialética ou não, a educação corporativa é apresentada como uma iniciativa colonizadora do capital e uma tradicional educação rural é criticada como uma "educação pública" desqualificadora da "gente do campo".

Assim, no verbete educação rural, Marlene Ribeiro (2012, p. 297) escreve o seguinte:

Deduz-se daí que a política educacional destinada às populações camponesas teve maior apoio e volume de recursos quando contemplava interesses relacionados à expropriação da terra $\mathrm{e}$ à consequente proletarização dos agricultores. Associado a esses interesses, identificava-se o projeto de implantação, por parte das agências de fomento norte-americanas, de um modelo produtivo agrícola gerador da dependência científica e tecnológica dos trabalhadores do campo. Deste modo, a educação rural funcionou como um instrumento formador tanto de uma mão de obra disciplinada para o trabalho rural quanto de consumidores dos produtos agropecuários gerados pelo modelo da agricultura importado.

Uma diferença radical justifica a criação de um modelo de educação dirigido ao campesinato e pelo campesinato. Uma nova educação vinda do campesinato e das suas instituições próprias de identidade, pensamento e luta, em oposição à educação rural, e também em uma linha de teoria e ação crescentemente distanciada da tradição da educação popular.

Os movimentos sociais não possuem controle algum sobre uma educação rural sob controle do poder de Estado, e a sua prática pedagógica na verdade difunde em "meio rural”, como vimos na citação acima, a mesma pragmática ideologia hegemônica do ensino público das escolas da cidade. Eis o sentido em que uma proposta de educação do campo pretende ser a sua contraface. A partir das experiências pedagógicas dos movimentos camponeses ela projeta a criação e a consolidação de uma educação escolar e paraescolar financiada pelo poder público, mas agora sob controle direto e pleno dos movimentos sociais do campo. ${ }^{9}$

No verbete de Educação Básica do Campo, Lia Maria Teixeira de Oliveira retoma a ideia central de uma educação ativamente contra-hegemônica centrada no protagonismo direto das classes e dos movimentos populares:

A rebeldia como sentimento/luta pela emancipação é um traço pedagógico de diversas populações campesinas, indígenas, caiçaras quilombolas, atingidas por barragens, de 
agricultores urbanos, que estão buscando a educação a partir de uma perspectiva contrahegemônica, conforme Gramsci nos ensina. ${ }^{10}$ Foi exatamente isso que produziu a diferenciação da Educação do Campo da histórica educação rural [grifos da autora]: o protagonismo dos movimentos sociais do campo na negociação de políticas educacionais, postulando nova concepção de educação que incluísse suas cosmologias, lutas, territorialidades, concepções de natureza e família, arte, práticas de produção, bem como a organização social, o trabalho, dentro outros aspectos locais e regionais que compreendem as especificidades de um mundo rural. (Caldart, 2012, p. 238)

Roseli Caldart nos acompanhará aqui em duas citações suas. Ela defende que a educação do campo não é mera modalidade pedagógica (educação) e geopolítica (do campo) que se contrapõe à educação das escolas rurais ofertadas pelo poder público. Ela é um fenômeno da realidade brasileira atual. Sem precisar lembrar o que aconteceu também, vindo do campo para a cidade, com a educação popular dos anos 1960, ela sugere que, no Brasil de agora, uma educação não apenas para camponeses, mas a partir de lutas originadas em seus movimentos, uma nova educação emerge com a proposta de recuperar uma radicalidade emancipatória talvez diluída ao longo dos anos. Vejamos como ela afirma isso em uma primeira citação:

A Educação do Campo nomeia um fenômeno da realidade brasileira atual [grifo da autora] protagonizado pelos trabalhadores do campo e suas organizações, que visa incidir sobre a política da educação desde os interesses sociais das comunidades camponesas. Objetivo e sujeitos remetem às questões do trabalho, da cultura, do conhecimento e das lutas sociais dos camponeses e ao embate (de classe) entre projetos do campo e entre lógicas da agricultura que têm implicações no projeto de país e de sociedade e nas concepções de política pública, de educação e de formação humana. (Caldart, 2012, p. 257)

Não muito diferente é o que escreve Caldart et al. (2012, pp. 275 e 279) em seus verbetes: educação ominilateral e educação politécnica. ${ }^{11}$ Ao lado de uma crítica direta e radical à oferta de educação através de políticas públicas (de governos do Partido dos Trabalhadores, logo, considerados como "de esquerda") um novo acontecer na educação brasileira, a partir da proposta da educação do campo, pretende também recolocar em termos de classe e de luta de classes algo que ao longo dos anos tenderia a haver sido diferenciado e diluído em boa parte das teorias da "reconceitualização" da educação popular a partir dos anos 1980. Em Frigotto, um educador especialista em educação e mundo do trabalho, tal como em outros educadores dialéticos, a categoria "cultura" dá lugar à categoria "trabalho", e uma ideia de "povo" como a coletividade ampliada de pessoas e coletivos da sociedade civil empenhados em frentes de lutas emancipatórias, retorna à ideia de povo como classe e de processos de transformação social como algo cujo chão é a luta de classes. ${ }^{12}$

A denominação educação do campo, constituída a partir do processo de luta do Movimento dos Trabalhadores Rurais sem Terra (MST), engendra um sentido que busca confrontar, a um tempo, perspectiva restrita, colonizadora, extensionista, localista e particularista da educação (crítica direta da escola pública oficial —CRB) e as concepções de natureza fragmentária e positivista de conhecimento. Por centrar-se na leitura histórica e não linear da realidade, o processo educativo escolar (da educação do campo - CRB) vincula-se à luta por uma nova sociedade, e, por isso, vincula-se também aos processos formativos mais amplos que articulam ciência, cultura, experiência e trabalho. (Caldart, 2012, p. 277) 
Retorno a Roseli Caldart. A partir dos documentos fundadores da Educação do Campo (alguns de seus autores escrevem com maiúsculas) ela lança mão de uma diferença entre preposições, para opor o "do" ao "para" e até mesmo ao "com", afim de fundar a radicalidade popular da educação do campo. Afinal, a quem no fim das contas uma educação pertence? Quem é não apenas o seu usuário, o seu destinatário ou mesmo um seu coagente, mas o seu criador, educador e gestor da educação?

Na sua origem o "do" da Educação do Campo tem a ver com esse protagonismo: não é "para" e nem mesmo "com": é dos trabalhadores, educação do campo, dos camponeses, pedagogia do oprimido... Um do que não é dado, mas que precisa ser construído pelo processo de formação dos sujeitos coletivos, sujeitos que lutam para tomar parte da dinâmica social, para se constituir como sujeitos políticos, capazes de influir na agenda política da sociedade. Mas que representa, nos limites impostos pelo quadro em que se insere, a emergência efetiva de novos educadores, interrogadores da educação, da sociedade, construtores (pela luta/pressão) de políticas, pensadores da pedagogia, sujeitos de práticas. (Caldart et al., 2012, p. 262). ${ }^{13}$

Em nome da proposta de uma nova educação do campo, através de diferentes convênios entre movimentos sociais populares e universidades brasileiras, são criados cursos e programas de estudos que vão da alfabetização de adultos a escolas para crianças e jovens de acampamentos e assentamentos da reforma agrária, e delas a cursos superiores de formação de educadores especialmente preparados para atividades pedagógicas "do campo", e não apenas "rurais". Cursos de Pedagogia da Terra em nível de graduação, de especialização e mesmo de mestrado formam anualmente uma nova modalidade de educadores no Brasil.

Deixo a outras pessoas a tarefa de descer bastante mais a fundo nessa questão cujo esboço apenas desenho aqui. Assim, quero encerrar este tópico perguntando se no momento presente não estaremos diante de pelo menos três vertentes no interior ou em áreas de fronteira, daquilo que em sua gramática mais ampla e generosa poderá ainda ser chamado de educação popular.

No canto à direita podemos situar as mais diversas iniciativas, entre a teoria e a prática, que associam uma cada vez mais polissêmica e, não raro, vaga ideia de educação popular a diversas vertentes e vocações de ações sociais e, de forma mais específica, daquelas que se apresentam como uma das várias modalidades de pedagogias fundadas em "princípios freireanos", redesenhados por releituras que os atualizam e/ou os ajustam a esta ou aquela direção especializada de uma educação vocacionada. A educação ambiental popular é um bom exemplo, assim como são outras as diferentes propostas de: educação para a paz, educação e direitos humanos, educações em nome de minorias sociais, étnicas ou sexuais.

No centro de nosso desenho situo a educação popular em sua tradição freireano-dialógica mais direta. Aqui estão situados educadores que se reconhecem como herdeiros em linha direta das propostas originárias da educação popular-dialógica. Aqueles que realizaram juntos, e como um acontecimento territorialmente latino-americano, o processo de reconceitualização. Aqueles que continentalmente reúnem-se em torno ao CEAAL, e que preservaram até hoje tanto uma diferenciada matriz essencialmente dialógica de ações pedagógico-políticas emancipatórias. No limite, situo aqui educadores que, mesmo quando leitores e usuários de teorias críticas provenientes do marxismo, não se consideram praticantes de uma educação dialética com base centrada na luta de classes, embora o povo e os movimentos populares sejam ainda reconhecidos como o eixo do protagonismo em processo de transformação social.

Finalmente, à esquerda de nosso desenho devo colocar as diferentes vertentes de algum modo afiliadas a uma leitura dialética da sociedade e da educação. Vertentes todas elas fundadas em leituras provenientes de alguma origem marxista e centrada no acontecer histórico da luta de classes. Acredito serem 
hoje cada vez mais raros os ativistas e educadores comprometidos diretamente com movimentos e processos de lutas populares que se consideram "organicamente freireanos", ou que ainda se assinam como educadores populares. Educadores que, mesmo quando preservam ainda algo das ideias originais de Paulo Freire, não o leem mais como o roteiro de seu mapa nas lutas de conquista de territórios e, menos ainda, como o porto de chegada.

Acredito ainda que a recente instauração da educação do campo no Brasil e no "campo" das lutas e propostas do Movimento dos Trabalhadores Rurais sem Terra e de outros movimentos afiliados constitui hoje o lugar social de teor político em que uma nova vertente de educação emancipatória surge e se afirma.

\section{Da Cultura ao Território}

Havia uma palavra geradora nos começos do que veio a ser a educação popular? Sim. E ela não era "educação", mas “cultura”. Relembro que cultura popular era o movimento que nos unia. Lembro também que na primeira experiência de alfabetização no Nordeste do Brasil, "fichas de cultura" destinavam-se a ser criticamente decodificadas pelos alfabetizandos em seus dialógicos "círculos de cultura". E a "ideia de cultura", entre uma filosofia e uma antropologia embrionária que desaguavam em uma pedagogia crítica, dialógica e "libertadora", atravessava todas as "fichas", da primeira à última. Relembro aqui que a sequência de nossas ações de então eram de algum modo estas: tornar uma pedagogia fundada na ideia de cultura uma ação pedagogicamente cultural; criar com o povo uma "nova cultura", a partir de mudanças de qualidade na consciência do educando, com um progressivo teor assumidamente político; dotar este "teor político" de um sentido contra-hegemônico orientado a ações transformadoras e emancipatórias.

Mesmo quando a atuação dos primeiros movimentos de cultura popular foi dirigida a camponeses e a comunidades rurais - e eles eram, em grande maioria - a relação entre a educação popular e uma luta popular pela terra era ainda vaga e francamente idealizada e difusa. Exceções foram as Ligas Camponesas da Paraíba e de Pernambuco.

Muitos anos mais tarde, a partir das frentes de lutas pela terra do Movimento dos Trabalhadores Rurais sem Terra e de outros movimentos camponeses equivalentes, associados a frentes de luta de povos indígenas e, logo a seguir, das inúmeras comunidades quilombolas, uma outra categoria, antes quase esquecida, sobrepõe-se à ideia geradora de "cultura" e passa a consolidar o próprio "chão" de uma emergente modalidade de educação, vinda diretamente dos movimentos camponeses. Sua palavra-chave é: "território".

Entre camponeses, indígenas e quilombolas, um horizonte para além daquilo que dá sentido a uma ação por conquista local e geográfica de terras ou de territórios desafia a desmontagem oficial e capitalista de uma ancestral geopolítica e de uma cartografia política do País. Trata-se agora de não apenas conquistar terra expropriada e transformada em latifúndio improdutivo ou entregue à voragem do agronegócio, assim como territórios ancestrais de índios e de negros cercados por grandes fazendas, quando não por empresas nacionais ou transnacionais de mineração e de exploração da madeira. Trata-se agora de, a partir da conquista ampliada de terras camponesas, quilombolas e indígenas, reescrever, de dentro para fora e de baixo para cima, toda uma nova cartografia popular.

Ora, desde então o educador vinculado a algum dos movimentos populares de luta geopolítica e social por territórios de vida e de sentido de vida, vê-se agora comprometido com uma luta em nome de ações político-pedagógico-cartográficas cuja "escrita" não se traduz apenas em e entre novos textos, mas também no e através de um redesenho inovador de novos mapas sociais. Não basta repronunciar, redizer ideologicamente o Brasil - ou a América Latina - como nos anos pioneiros e depois deles. É preciso remapear geopoliticamente o País e o Continente. 
Da floresta para o campo e do campo para a cidade (pois também nela inúmeros movimentos sociais dos "sem-teto" estão ativos) diferentes atores sociais apagados, desconhecidos, mal conhecidos, demonizados ou folclorizados, agora entram em cena e, sem máscaras, "mostram sua cara". Camponeses, caiçaras, seringueiros, castanheiros e outros "povos da floresta", povoadores de quilombos, de terras-de-santo, de faxinais, de fundos de pasto, ao lado dos inúmeros povos e das tribos indígenas das etnias do Brasil saem a campo. Saem organizados em frentes de luta, e a partir de suas difíceis, lentas, mas sucessivas conquistas nos ajudam a reinventar o "mapa do Brasil", e a recriar uma nova e real cartografia social.

“Território", "territorialização", "processos de territorialização"; essas palavras apenas técnicas entre geógrafos do passado recente assumem com as frentes de lutas dos movimentos camponeses, quilombolas, indígenas e outros uma conotação francamente pedagógica, e, portanto, emancipadoramente política. Esse novo dizer-e-mapear passa a significar não apenas algo que ao longo da história de um povo demarca uma "natural" expansão de fronteiras e uma ocupação de território. Ele ousa ressignificar todo um processo ativo de reconquista de territórios usurpados historicamente, ao lado de uma reescrita de cartografias. Novas leituras da vida e dos lugares-da-vida que passam de uma geografia física onde as ações humanas são quase complementares, a uma crítica geopedagógica em que as ações humanas recriam e significam agora o próprio "físico" de um território.

Sem esquecer todo o labor de movimentos sociais populares de vocação urbana e todo o trabalho de educação popular realizado entre fábricas e favelas, uma vez mais, como na aurora dos anos 1960 no Nordeste do Brasil, é do campo e do campesinato que uma polissêmica e desafiadora reescrita de alternativas de educação dos movimentos populares e a serviço dos movimentos populares emerge. É no bojo dos movimentos que em boa medida acabam de publicar o Relatório da Comissão Camponesa da Verdade, que uma educação popular para o século XXI desloca de uma então ainda vaga "ideia de cultura", para a concretude geopolítica do "território", não apenas o lugar social, mas toda uma simbologia de frentes de luta e de conquistas. ${ }^{14}$

Sem que teorias, propostas e práticas de teor freireanos tenham perdido ou estejam perdendo ao longo da América Latina a sua atualidade, acredito que, no percurso de sua trajetória, elas fazem interagir diferentes focos e eixos de ação emancipatória, na mesma medida em que, sem esquecer os seus primeiros passos, elas saltam de uma antropopedagogia da cultura junto ao povo, para uma sociopedagogia dos movimentos populares. E, desde ela e através dela, convergem a uma geopedagogia cartográfica das lutas populares por conquista de territórios. ${ }^{15}$

Há uma passagem de Miguel Arroyo, em um dos verbetes do Dicionário da Educação do Campo, que traduz com felicidade o que descrevo aqui. No fluxo de ações do Movimento dos Trabalhadores Rurais sem Terra e de outros movimentos da Via Campesina, desde uma luta de trinta anos em favor não apenas de uma reforma agrária, mas de toda uma transformação da sociedade brasileira através de conquistas populares sobre a terra, perpassa uma ideia que polissemiza e amplia o sentido e o teor simbolicamente político e pedagógico de "território".

Convivemos com vários e entrelaçados territórios geográficos, sociais e culturais expropriados, desde os quais lutamos em nome de reconquista não somente de terras, mas de saberes, sentidos e significados que foram expropriados junto com a terra, e envolve justamente a educação e o seu lugar social mais eloquente: a escola. Através de projetos de criação popular de um outro saber, um lugar social a ocupar militantemente é o território-escola. Eis o que Miguel Arroyo (2012, pp. 559-560) anota no verbete Pedagogia do Oprimido: 
traço mais radical: ocupar o território-escola. Os movimentos sociais, ao lutarem por terra, espaço e território, articulam as lutas pela educação, pela escola - as lutas por direitos a territórios. Mostram a articulação entre todos os processos históricos de opressão, segregação e desumanização, e reagem lutando em todas as fronteiras articuladas de libertação. Escola é mais do que escola na pedagogia dos movimentos. Ocupemos o latifúndio do conhecimento como mais uma das terras, como mais um dos territórios negados.

A escola, a universidade e os cursos de formação de professores do campo, indígenas e quilombolas são mais outros territórios de luta e de ocupação por direitos. A negação, a precarização da escola, é equacionada como uma expressão da segregação-opressão histórica da relação entre classes. Já a escola repolitizada é mais um território de luta e ocupação, de libertação da opressão. A Pedagogia do Oprimido é radicalizada na pedagogia escolar pelas lutas dos movimentos por educação do campo, por escola do campo no campo. ${ }^{16}$

Aquilo que nos anos 1960/70 atribuíamos à cultura e compreendíamos como a tarefa pedagógica de uma educação popular entendida como uma região da cultura, ao mesmo tempo em que tratávamos de atribuir - com a companhia frequente de Antônio Gramsci - à ideia de cultura o seu esquecido teor político, é agora retomado, sobretudo pela educação do campo, como uma cartografia de valor político-popular que recoloca no "chão da história" os termos das alternativas de uma educação emancipatória de movimentos indígenas, quilombolas, populares, enfim.

Tanto "naqueles tempos" como agora a história se repete e, como em Marx, redesenha, entre velhos e novos termos - como "capitalismo neoliberal" ou "globalização" — ora a sua farsa, ora a sua tragédia. Ontem como hoje há expropriações que são simbólicas, há apropriações que são culturais, há latifúndios que são de saberes e, mais do que "naqueles tempos", há não apenas pessoas - entre quase-escravos e operários mal pagos - produtores de mercadorias, mas um sistema de mercado que transforma agora as pessoas em mercadoria. Há, portanto, lutas de conquistas territoriais que devem operar também nesses e sobre esses domínios.

Mesmo devendo confessar por escrito que não me aprofundei devidamente neste tema, devo dizer que acredito que com uma força talvez ainda inadvertida entre nós, a educação popular - tomada aqui em seu sentido mais generosamente abrangente - mescla-se com a ideia de território em pelo menos duas direções: uma delas é mais antiga e a outra mais atual, pelo menos quando associada a novas formas de ação pedagógica desde movimentos populares do campo.

A primeira está no fato de que, com o advento da educação popular - como um acontecer cultural situado e datado - , ao lado de um diálogo crescente entre movimentos sociais do continente, uma nova geografia política da América Latina surge e se impõe. Em direção diversa do currículo oficial de nossas escolas públicas, uma leitura de América Latina e Caribe (e, por extensão, todo o mundo) nos obriga a desfronteirizar toda uma "história nacional nacionalista" que até hoje ocupa quase todos os livros de nossas "histórias pátrias". Enquanto as empresas multinacionais de agronegócio (Monsanto, por exemplo) "globalizam" terras e territórios, frentes indígenas e camponesas de lutas emancipatórias "desterritorializam" falsas fronteiras em nome de não apenas territórios, mas de povos emancipados. Povos que, justamente por estarem lutando por sua emancipação, podem incorporar à mesma luta um outro mapa popular de um mundo afinal sem fronteiras, ou com fronteiras afinal aberta $\grave{a}$ acolhida dos outros-que-não-nós.

A segunda reside a meu ver na evidência de que, sobretudo entre camponeses militantes da Via Campesina e, mais ainda, através dos movimentos dos povos testemunhos (indígenas e outros), entre os Andes e a Amazônia uma nova endoeducação associa-se a uma luta emancipatória vivida em nome de não apenas a afirmação de direitos a territórios ancestrais e à salvaguarda de modos patrimoniais de ser e 
de viver. Vivida e praticada também em nome da expansão de saberes, sentidos e significados ancestrais e assumidamente primitivos que, desde a selva à cidade, propõem-nos com uma inocente e aguerrida ousadia, outras formas de pensar, de sentir, de viver e de ser. Novas alternativas do imaginário e da vida que poderiam acrescentar aos novos saberes e valores ainda acentuadamente ocidentais e europeus, toda uma outra ciência. $\mathrm{Ou}$, mais ainda, um outro saber menos subalterno à ciência e mais atento e aberto à sabedoria.

\section{Notas}

1. Este poderia ser o momento oportuno para lembrar que o Instituto Paulo Freire editou, junto com outras instituições do Brasil, a Pedagogia do Oprimido em edição fac-símile. Na edição do manuscrito de Freire é possível descobrir passagens importantes e pequenos esquemas desenhados que não constam das edições "oficiais". É possível notar também a presença de um tópico com este nome: teoria da revolução, que não aparece nas edições oficiais. Lembro ainda que, desde os Estados Unidos da América e a caminho de seu exílio na Europa, Paulo Freire enviou o manuscrito de Pedagogia do Oprimido para Jacques Chonchol, no Chile, dando a ele liberdade de fazer do manuscrito o que lhe parecesse melhor. Há até agora entre nós dúvidas sobre como a Pedagogia do Oprimido foi originalmente. Existe mesmo a estranha versão de que a obra foi originalmente publicada em inglês e nos EUA. Foi depois editada em espanhol e, somente anos mais tarde, publicada no Brasil.

2. Norma Elizabeth Pereira Coelho defendeu na Faculdade de Educação da Universidade Federal do Rio Grande do Sul uma tese de doutorado sobre esse assunto: os libertários e a educação no Rio Grande do Sul (1895-1926), Porto Alegre, 1987.

3. No tópico: "Los inicios - La educación liberadora de Paulo Freire", quando Carillo comenta justamente a conjuntura brasileira do começo dos anos 1960. Chamo a atenção para a expressão "liberadora", indicativa de que a própria palavra "popular" no começo dos anos 1960 no Brasil não qualificava a proposta pedagógica de Paulo Freire, mas servia apenas para unificar a ideia de uma "cultura popular", de que uma "educação liberadora" seria uma dimensão e uma frente de ações entre outras.

4. Em uma recente consulta sobre a educação popular realizada pelo CEAAL, responderam 118 instituições da sociedade civil afiliadas à educação popular, provenientes de praticamente todos os países da América Latina. (Torres Carrillo, 2012, pp. 139-140).

5. No Brasil, ademais das "escolas antroposóficas" existem em alguns estados da União "escolas logosóficas". São escolas criadas a partir do pensamento de Carlos Bernardo González Pecotche - Raumsol - um pensador argentino cujas ideias encontraram inúmeros seguidores no Brasil, onde todos os seus livros foram traduzidos. Existe um Sistema Logosófico de Educação, e no Paraná há um Instituto Gonzáles Pecotche. Raumsol criou uma primeira escola logosófica em Córdoba, na Argentina. Ignoro se existe em seu país, tal como no Brasil, uma "rede de escolas logosóficas".

6. Está nas páginas 77 e 78 de Educación popular - trayectória y actualidad. É curioso que na bibliografia ao final do livro o autor tenha esquecido de mencionar o seu livro de 2000, lembrado na citação.

7. Dentre os vários livros e artigos de Demerval Saviani a respeito de sua proposta pedagógica talvez um dos mais importantes para a sua compreensão seja Pedagogia Histórico-Crítica, publicado em 2000, pela Editora Autores Associados, de Campinas. 
8. O surgimento da expressão "educação do campo" possui datas bem definidas. Em um primeiro momento ela e a sua proposta surgem com este nome: educação básica do campo, durante os momentos de preparação da I Conferência Nacional por uma Educação Básica do Campo, realizada em Luziânia, Goiás, de 27 a 30 de julho de 1998. Poucos anos mais tarde ela passou a ser oficialmente denominada educação do campo a partir de um seminário nacional, realizado em Brasília, de 26 a 29 de novembro de 2002 A decisão do novo nome foi depois reafirmada nos debates da II Conferência Nacional, realizada em julho de 2004.

9. Como política de movimento social popular, o Movimento dos Sem-Terra (MST) estabelece acordos a níveis nacional, estadual e municipal com o poder público. Lembro que no Brasil o "ensino fundamental" é competência de governos municipais, embora haja uma legislação nacional de educação, cujas leis e fundamentos são alterados periodicamente. Há um entendimento de que o Governo Federal financia as escolas do MST (mais de 1.800 no país), através sobretudo do PRONERA (um programa de apoio à educação do Instituto Nacional da Reforma Agrária). No entanto entende-se que quem estabelece diretrizes de educação escolar e de jovens e adultos nos acampamentos e assentamentos da reforma agrária são coletivos do MST. Em seu verbete, Roseli Caldart (2012, p. 262) defende com todas as letras que não cabe ao poder de estado e nem a qualquer política governamental a gestão ideológica e pedagógica da educação do campo. Ela o expressa da seguinte maneira: "A Educação do Campo, principalmente como práticas dos movimentos sociais camponeses, busca conjugar a luta pelo acesso à educação pública com a luta contra a tutela política e pedagógica do Estado (reafirma em nosso tempo que não deve ser o Estado o educador do povo [grifos da autora])".

10. Lembro que no caso brasileiro - e ele poderá ser comum em outros países da América Latina - os movimentos sociais mais mobilizados dividem-se de acordo com os seus sujeitos étnicos, culturais e sociais. E, embora formem uma ativa "frente única", inclusive contra políticas e omissões governamentais recentes, guardam as suas especificidades. Assim, existem várias frentes de luta: de povos indígenas, de comunidades quilombolas e de movimentos de negros, de pescadores ribeirinhos ou marinhos (caiçaras), de populações rurais desalojadas por barragens e hidroelétricas, de diferentes "povos da floresta" na Amazônia (seringueiros, castanheiros), ao lado de agremiação sindicais e de classe no campo e na cidade. Alguns deles encontram em instituições da Igreja Católica os seus mais ativos e persistentes apoiadores, como o Conselho Missionário Indigenista (CIMI) e a Comissão Pastoral da Terra (CPT).

11. Seus dois verbetes vão da página 265 à página 279 do Dicionário da Educação do Campo.

12. Chamo a atenção para o fato de que em seu verbete no mesmo dicionário: educação popular e educação do campo - nexos e relações, Conceição Paludo, uma educadora popular de linha freireana, dialoga com Marx, com Ricardo Antunes (sociólogo marxista especializado em mundo do trabalho) com João Pedro Stédile, ideólogo do MST, com Demerval Saviani e com Gaudêncio Frigotto. Já em seu verbete educação popular e sistematização de experiências, Oscar Jara deixa de fora educadores e outros pensadores de linha dialética entre os lembrados por Conceição Paludo e outros.

13. Está na página 5 de um documento originalmente mimeografado em Porto Alegre, com este nome: Educação do campo - notas para uma análise do percurso. A mesma citação pode ser encontrada no artigo de Ademar Bogo, um conhecido militante do MST: A questão da educação do campo e as contradições da luta pelo direito, p. 96. $\mathrm{O}$ artigo de Ademar Bogo é um dos escritos de um livro bastante recomendável a quem se interesse pelo próprio surgimento e o processo de consolidação muito recentes de uma Educação do Campo. O livro é: Educação do Campo e contemporaneidade - paradigmas, estratégias, possibilidades e interfaces. O livro foi publicado em 2013 pela Editora da Universidade Federal da Bahia, onde se concentra um dos mais ativos coletivos vinculados à educação do campo, sob coordenação do professor Antônio Dias Nascimento. O livro contém também o importante 
documento do Fórum Nacional de Educação do Campo (FONEC), notas para análise do momento atual da Educação do Campo, celebrado em Brasília entre 15 e 17 de agosto de 2012.

14. Este documento, que levou anos para ser elaborado e cujo conhecimento está ainda restrito a círculos muito pequenos, acaba de ser publicado. Transcrevo aqui o começo da introdução do relatório: "Em 2012 foi criada a Comissão Camponesa da Verdade (CCV), um dos frutos do Encontro Unitário dos Trabalhadores, Trabalhadoras e Povos do Campo, das Águas e das Florestas. Este evento reuniu, em Brasília, em 2012, milhares de camponeses de mais de quarenta organizações e movimentos ligados à luta pela terra e por territórios, em memória ao 1o Congresso Camponês, realizado em 1961, em Belo Horizonte. Além de celebrar os mais de cinquenta anos do congresso de Belo Horizonte, o Encontro Unitário articulou a diversidade das organizações do campo na construção de alternativas políticas, econômicas e sociais ao agronegócio para o campo brasileiro. Alternativas e bandeiras baseadas na defesa da reforma agrária, no respeito ao meio ambiente, na produção de alimentos saudáveis e na soberania alimentar, na defesa dos direitos territoriais, na geração de renda e na melhoria da qualidade de vida no meio rural, entre outras bandeiras e lutas".

15. E não apenas no Brasil. Sobretudo nos países marcadamente pluriétnicos, como a Bolívia, o Equador, o Peru, a Colômbia, os da América Central e Caribe, o México e o Brasil, etnia-e-território somam-se agora como duas frentes sociais e simbólicas de uma mesma luta popular. Nesse sentido, recomendo alguns pequenos (grandes) livros de uma nova coleção de estudos populares colombianos. A Ediciones Desde Abajo está publicando uma Colección Primeros Pasos, dirigida a ativistas populares e a movimentos e instituições de mediação. Entre os seus primeiros livros recomendo especialmente: Producción social del espácio; El capital y las luchas sociales em la disputa territorial, de Carolina Jiménez e Edgar Novoa; Hacer história desde Abajo u desde el Sur, de Alfonso Torres Carrillo.

16. Essa longa passagem faz parte do verbete Pedagogia do Oprimido, que vai da página 553 à página 560 do Dicionário da Educação do Campo. A citação de Miguel Arroyo está nas páginas 559 e 560 . A ideia de territórios simbólicos, logo culturais e pedagógicos e de uma luta popular por territorializações outras, está presente em recentes trabalhos do educador colombiano Marco Raul Mejía. Mejía é hoje um dos mais fecundos e ativos educadores populares em diálogo com o momento presente, sobretudo da América Latina e um dos mais lúcidos críticos dos processos atuais de colonização simbólica, entre a mídia e a escola. Ver indicações dos livros na bibliografia.

\section{Referências}

ARROYO, M.G. Pedagogia do Oprimido. In: R.S. CALDART et al. (Org.). Dicionário da educação do campo. Rio de Janeiro: Escola Politécnica de Saúde Joaquim Venâncio, Expressão Popular, 2012. p. 553-560.

CALDART, R.S. et al. Dicionário da educação do campo. Rio de Janeiro: Escola Politécnica de Saúde Joaquim Venâncio, 2012.

COELHO, N.E.P. Os libertários e a educação no Rio Grande do Sul (1895-1926). 1987. 152f. Dissertação (Mestrado em Educação) - Universidade Federal do Rio Grande do Sul, Porto Alegre, 1987.

DUSSEL, E. Política da libertação: História mundial e crítica. Passo Fundo: IFIBE, 2014.

ESTEBAN, M.T.; TAVARES, M.T.G. Educação popular e a escola pública - algumas questões e novo horizontes. STRECK, D.; ESTEBAN, M.T. (Orgs.). Educação popular: lugar de construção social. Petrópolis: Vozes, 2013. p. 293. 
FAVERO, O. Cultura popular e educação popular: Memória dos anos 60. Rio de Janeiro: Graal, 1986.

FREIRE, P. Pedagogia do Oprimido. São Paulo: Instituto Paulo Freire, 2014.

GADOTTI, M.; TORRES, C.A. Educação popular: Utopia latino-americana. São Paulo: Cortez, 1994.

IBÁNEZ, A.; NOEL AGUIRRE, L. Buen vivir, vivir bien: Una utopía en proceso de construcción. Bogotá: Desde Abajo, 2013.

JAEGER, W. Paideia: a formação do homem grego. São Paulo: Martins Fontes, 2009.

JIMÉNEZ MARTÍN, C.; NOVOA TORRES, E.A. Producción social del espacio: El capital y las luchas sociales en la disputa territorial. Bogotá: Desde Abajo, 2014.

NOVAES, A. A invenção das crenças. São Paulo: Edições SESC/SP, 2011.

NOVAES, A. Civilização e barbárie. São Paulo: Companhia das Letras, 2004.

OSCAR JARA, H. La sistematización de experiencias: Práctica y teoría para otros mundos posibles. Colleción: Educación popular y saberes libertários. Lima: Centro de estudios y publicaciones ALFORJA/ CEAAL, 2014.

SAVIANI, D. Pedagogia histórico-crítica. Campinas: Autores Associados, 2000.

TOLSTOI, L. Os últimos dias. São Paulo: Companhia das Letras, 2011.

TORRES CARRILLO, A. La educación popular: Trayectoria y actualidad. Bogotá: El Buho, 2012.

TORRES CARRILLO, A. Hacer história desde Abajo y desde el Sur. Bogotá: Desde Abajo, 2011.

\section{Sobre o Autor}

Carlos Rodrigues Brandão é bacharel em psicologia e psicólogo pela Pontifícia Universidade Católica do Rio de Janeiro (1965-1969). Possui mestrado em Antropologia pela Universidade de Brasília (1974) doutorado em ciências sociais pela Universidade de São Paulo (1980) e livre docência em antropologia do simbolismo pela Universidade Estadual de Campinas (1989). Realizou estudos de pós-doutorado em antropologia junto à Universidade de Perugia e à de Santiago de Compostela (1992). Aposentou-se da UNICAMP em 1997, após vinte e três anos de trabalhos lá e de trinta anos como professor. Permanece como docente dos quadros do Doutorado em Antropologia e do Doutorado em Ciências Sociais da UNICAMP. Possui experiência em antropologia, com ênfase em antropologia rural, atuando principalmente nos seguintes temas: cultura, educação popular, campo religioso, rituais populares e religião. Desde 1963 trabalha com educação, sobretudo nas áreas de educação popular e educação ambiental. É membro do Conselho Internacional e consultor do Instituto Paulo Freire. É comendador da Ordem do Mérito Científico, do Ministério de Ciência e Tecnologia; Professor Emérito da Universidade Federal de Uberlândia, Doutor Honoris Causa pela Universidade Federal de Goiás, Doutor Honoris Causa da Universidad Nacional de Lujan - Argentina; Professor Emérito da Universidade Estadual de Campinas. 